Würzburg Castle-the most striking feature of which was a large collection of the sculptures of Tilman Riemenschneider (1460-1531) - were the main social items in the proceedings, which were essentially informal. As in the case of the Halle celebrations, detailed reports will be published in the Nova Acta Leopoldina, including a full account of Prof. Gallwitz's researches. But, as yet, no copies of the current year's issue have reached the British bodies who were recipients before the War (and whose publications have been received up to date by the Academy), although at the time of the Halle meeting it was hoped to make up the deficiency forthwith.

R. C. H. Young

\section{FARM WATER SUPPLIES}

$\mathrm{O}$ October 21, under the auspices of the Society for Applied Bacteriology, a series of papers were read on various aspects of "Farm Water Supplies". The introductory paper was given by Mr. G. 'T. Morgan (Ministry of Agriculture and Fisheries), who at the outset emphasized the great importance of cleanliness in milk production and the significance of water supplies in this connexion. Of the 158,000 milk producers in Great Britain, 40 per cent own less than ten cows, and a large proportion still have inadequate and unsatisfactory water supplies to meet the estimated daily requirement of some 30-35 gallons per animal. With so many small units it is difficult to effect immediate improvements, particularly when so many of them have been producing satisfactory milk for many years. Information is being collected continuously, supplies are checked, and advice is given for improving their quality; reasonable time being allowed to correct faults and to effect the desired improvements.

Sir William Savage (Taunton), the eminent authority on public health matters, emphasized the need for a practical approach to the problem, since it is clear that piped supplies for all agricultural purposes are not possible, first on economic grounds and, secondly, because there is not sufficient water available. The quantities and qualities required must, therefore, be related to their uses. On only rare occasions have water supplies been incriminated in epidemics of bacterial infection, and in these cases the Salmonella and enteric organisms have been involved. Moreover, for most dairying purposes, the standards of water supplies need not be as high as those for general domestic supplies. Well and stream waters are quite satisfactory for animal drinking and for byre washing. Pure supplies are essential for washing all surfaces which come into direct contact with the milk. Sir William was sceptical of chemical disinfection, since this is usually carried out by unskilled farm hands.

Mr. W. A. Cuthbert (Leeds) said that 97 per cent of farm water supplies are from wells, usually shallow ones, or from springs. By means of a series of lantern slides he illustrated the unsatisfactory nature of many such wells and the difficulties of tracing the real sources of some of the springs. Infection in these waters are mainly found to be due to human pollution, which can be eliminated by appropriate protective measures, although these often involve reconstruction. Chlorination should also be employed, but this cannot be relied upon entirely to render a bad water safe. In farm water supplies, the counts of Bact. coli and coli-aerogenes groups vary independently, so that differentiation of fæcal and non-fæcal organisms is of little value for diagnostic purposes. Topographical examination of all supplies is essential and should be considered along with bacteriological findings before expressing judgment on any supply. Numerical standards for bacterial content are in themselves of no value in assessing farm water supplies because of the considerable seasonal variations encountered. Investigation has shown that factors responsible for this variation include soil temperature and, to a less extent, rainfall.

Dr. J. H. McCoy (Hull), considering the significance of polluted farm water supplies in relation to human infection, said that standard bacteriological tests cannot of themselves guaranteo the non-pathogenicity of any supply. Topographical examination is a first essential to eliminate obvious faults. Epidemics of milk-borne enteric infections are traceable mainly to carriers, but a small number is undoubtedly attributed to the water supply, for example, the Croydon epidemic of 1937. Dr. McCoy also directed attention to organisms likely to cause spoilage in dairy products, such as lipolytic and proteolytic bacteria in cheeses, but said that these should not be present in large numbers in properly handled milks. Mr. T. C. Ketchen (Ministry of Agriculture and Fisheries), again emphasizing the practical and financial aspects, described in detail several ways in which the design and maintenance of farm water systems could be improved. Examples were given of how these could be effected by fencing off springs and wells from animal contact, by substituting bore-holes for shallow wells, by re-directing and piping flows from springs, or by proper walling and fencing of well-mouths.

The discussion was opened by Dr. Windle Taylor, who emphasized the importance of chemical tests on waters, and expanded further the significance of the Bact. coli/coliform ratio, stating that fæcal Bact. coli appears to survive much longer in water than was originally thought.

\section{INTERNATIONAL SANITARY REGULATIONS}

$\mathrm{F}$

OR more than a hundred years the progressive nations of the world have endeavoured to arrange a uniform sanitary code to govern international traffic and to utilize the best preventive measures against the importation of infectious diseases, especially cholera, plague and yellow fever. Important work to this end was done by the PanAmerican Sanitary Bureau, the Office International d'Hygiène Publique, and the Health Organization of the League of Nations ${ }^{1}$. The development of air travel led to the International Sanitary Convention for Aerial Navigation, afterwards modified in 1944, like the convention of 1926 for maritime traffic.

During the first half of the present century there were as many as thirteen conventions or diplomatic arrangements relating to health control measures to be taken at frontiers. None of these conventions completely superseded all its predecessors, nor were all the States parties to these arrangements, some participating in certain of them and not in others. This disunity caused trouble and confusion in international traffic. Further defects were the delay in ratification, which prevented the application of the agreed measures rapidly and simultaneously; and 